\title{
The Relationship of the Industry with the Public Administration: Best Practices on Co-regulation for Training
}

\author{
María de-Miguel-Molina, Virginia Santamarina-Campos, \\ and María-Ángeles Carabal-Montagud
}

\begin{abstract}
In the different European countries, co-regulation is used to provide theoretical and practical training to the civilian drone pilots. In this chapter, we present the process required to become an authorised training organisation, and we explain how manufacturers and operators are also involved in this task. The assessment of civil drone pilots is delegated from the public administration to non-governmental organisations and therefore trust is a key factor in this publicprivate partnership. Therefore, in this chapter we reflect on the characteristics of co-regulation within the civilian drone sector and how the industry is involved in this activity to evaluate the pilots' capacity. As we can observe, if public administration gives precise guidelines to the industry, it contributes to better decision-making, although other stakeholders are frequently left out of the process. Moreover, the approval of the European framework is urgent to give more support to the regulation of the sector and to increase the possibilities of co-regulation.
\end{abstract}

\section{Introduction}

New public-private models propose joint decision-making between companies and stakeholders such as the public administration (co-regulation). The European Aviation Safety Agency (EASA), as an Agency of the European Union, promotes the highest common standards of safety and develops common safety rules at the European level. This agency and their national equivalents monitor the activity of producers and operators of civil drones, but depending on the size of the drone, this activity could involve regulation measures or not, in which case other alternatives such as co-regulation can be used. The co-regulation tool, although a soft instrument,

M. de-Miguel-Molina ( $\triangle$ )

Management Department, Universitat Politècnica de València, Valencia, Spain

e-mail: mademi@omp.upv.es

V. Santamarina-Campos · M.-Á. Carabal-Montagud

Conserv. \& Restoration of Cult. Heritage Department, Universitat Politècnica de València,

Valencia, Spain 
is a useful public-private alternative for the manufactures and operators of civil drones.

The regulation of drones (UAVs, Unmanned Aerial Vehicles) and, in particular, RPAs (Remotely Piloted Aircrafts) of less than $150 \mathrm{~kg}$ depends on their national regulations. These regulations are mainly focused on safety parameters during the design of civil drones, which are applied to the manufacturers and different services offered by the operators. In the case of the civil drones, the point is to achieve the necessary interaction among stakeholders to produce a consensus of a public policy approach in an area where there is considerable uncertainty (Freeman and Freeland 2014).

The European Union has developed some documents in order to clarify the regulation of civil drones. Current national harmonisation actions undertaken by EASA define riskless open and riskier specific categories (Stöcker et al. 2017). And this is the tendency that the new European Regulation seems to follow by soon establishing different categories (De-Miguel-Molina and Santamarina-Campos 2018).

Moreover, in January of 2018 the Council of the European Union presented the final version of the text agreed upon with the European Parliament on the "Proposal for a Regulation of the European Parliament and of the Council on common rules in the field of civil aviation and establishing a European Union Aviation Safety Agency" (Council of the European Union 2018). This regulation seems that it will be approved around April, and it presumes the necessity of more control over specific drones (probably the riskier ones).

According to its Annex IX, section 4.2, "operators of drones shall be registered where they operate any of the following:

(i) unmanned aircraft which, in the case of impact, can transfer to human kinetic energy above 80 Joules;

(ii) unmanned aircraft, the operation of which presents risks to privacy, protection of personal data, security or the environment;

(iii) unmanned aircraft, the design of which is subject to certification pursuant to Article 46(1)".

That is, taking into account the nature and risk of the activity concerned, the operational characteristics of the unmanned aircraft concerned and the characteristics of area of operation, a certificate may be required for the design, production, maintenance and operation of unmanned aircraft and their engines, propellers, parts, non-installed equipment and equipment to control them remotely as well as for the personnel, including remote pilots, and organisations involved in these activities (article 46).

As we can observe, from a starting point, all drone regulations have one common goal: "minimizing the risks to other airspace users and to both people and property on the ground" (Stöcker et al. 2017). Therefore, national regulations frequently cover the following points:

- Technical requirements (regarding the product).

- Operational limitations (concerning the flight).

- Administrative procedures (certificates, registration, insurance). 
- Human resources requirements (qualification of pilots).

- Implementation of ethical constraints (data protection and privacy).

In this case, we will focus on administrative procedures and human resources requirements, but the rest of the points can be found in de-Miguel-Molina and Santamarina-Campos (2018).

To reach a common legal framework, the European Union has developed several stakeholder consultations, although no legislation has been approved yet. Industrial manufacturers and professional users are expected to play a key role and contribute to the decision as to whether drones are going to be a tool for everyone or just for professionals.

In our case of study, the assessment of the civil drone pilots, we find this to be a key factor for the industry (Clarke 2016). Moreover, requiring pilots and operators to be licensed and have insurance can impose standards and ensure safety even when they are not compulsory.

\section{The Concept of Co-regulation and the Case of the Training for Civil Drone Pilots}

When a non-governmental institution participates with the public administration in regulating a sector, this task can be called "co-regulation". As Höffe (2007) highlights, this is an expansion of the citizens' participation. When some organisations, or even citizens, can apply their power in particular themes, it can be stated that they work in a "transition zone" among the government and the civic (or civil) society. That is, the Third Sector's zone (Catalá Pérez 2017).

The Australian Communications and Media Authority (ACMA 2011:5), points out that "co-regulation generally involves both industry and government (the regulator) developing, administering and enforcing a solution, with arrangements accompanied by a legislative backstop. Co-regulation can mean that an industry or professional body develops the regulatory arrangements, such as a code of practice or rating schemes, in consultation with government. While the industry may administer its own arrangements, the government provides legislative backing to enable the arrangements to be enforced".

Other authors refer to this kind of participation as "meta-regulation" or "metagovernance". According to Peters (2010:37), "it recognises the need for some delegation and devolution of governing but at the same time recognises the need for greater central direction".

Moreover, Sanderson (2011) presents co-regulation as the way of "sharing regulatory responsibilities between the state and regulatees". He emphasises more features of co-regulation:

- It operates within a legislative framework which empowers the regulator to take action in cases of non-compliance, 
Table 1 Co-regulation characteristics of the theoretical and practical training for civilian drone pilots

\begin{tabular}{l|l|l}
\hline Characteristic & Definition & Application \\
\hline Target & Entity which the regulation applies & $\begin{array}{l}\text { Civil drone pilots, operators, manufac- } \\
\text { turers, and ATOs }\end{array}$ \\
\hline Regulator & $\begin{array}{l}\text { Entity that creates and enforces the } \\
\text { rule of regulation }\end{array}$ & Government, Aerial Agencies \\
\hline Command & $\begin{array}{l}\text { What to do or what refrain from } \\
\text { doing }\end{array}$ & $\begin{array}{l}\text { Acquired all the documents to prove } \\
\text { training }\end{array}$ \\
\hline Consequences & $\begin{array}{l}\text { What happens if command is not } \\
\text { followed }\end{array}$ & $\begin{array}{l}\text { Administrative sanctions for the protec- } \\
\text { tion of public safety }\end{array}$ \\
\hline
\end{tabular}

Source: own elaboration from Coglianese and Mendelson (2010)

${ }^{\mathrm{a}}$ Authorised training organisations

- It enhances legitimacy as regulatees are also involved,

- It relies on high levels of trust between regulator, regulatees and citizens,

- The regulator manages the process as an "equilibrator".

Clarke and Bennett Moses (2014:268) give different power to the actors of a specific regulatory form and, in the case of co-regulation, they stress that the state and the industry "negotiate what and how", while corporations contribute to the industry and other stakeholders "may or may not have some influence". But, from their point of view, in the European drone sector, neither EASA nor the European Commission "show much evidence of engagement with stakeholders outside the industry" (278).

Following Coglianese and Mendelson's (2010) essentials characteristics of regulation, in Table 1 we show how the co-regulation of the theoretical and practical training of civil drone pilots could be considered.

On the other hand, co-regulation can present negative consequences (Peters 2010), which we have analysed:

- Decision-making can be influenced by the interests of the separate parties involved. However, we do not think that this applies to the pilot training, as the requirements of the examinations are quite specific by the regulation. Therefore, decision-making is in fact very limited.

- Some stakeholders are less capable of influence decisions. As highlighted by Clarke and Bennett Moses (2014), we agree in some way. Even if the European Commission has made efforts to open consultations with different stakeholders, National regulations do not always make this process possible.

- More organisations need coordinating. Of course, that could be a problem, but again the regulation can be precise enough to avoid this risk.

- Finally, this mechanism may not substitute for the government responsibility for public action. We are of the same opinion that, in the case of an accident with a drone, public administration is co-responsible if the training approved did not fulfil the standards. 
In this sense, we think that some national regulations can be taken as "best practices", although the way to regulate in each country could differ from one to another. Anyway, we should "recognise that greater flexibility will be needed for operating in an environment of innovation and constant change" (ACMA 2011:11).

\section{Analysis}

Our study is based on a content analysis from different sources of information: academic papers, regulation proposals from the European Union and the regulation of some European countries (mainly, we will focus on the Spanish current regulation, which was the last to come into force in the EU in December 2017). From a comparative analysis of the results, we evaluate the different co-regulations of the National Laws.

As we observe, co-regulation is normally used to provide theoretical and practical training to the pilots of civilian drones. For example, in Spain the National Agency of Aerial Safety (AESA 2017a) works with different organisations to provide theoretical and practical training to pilots. But we think that this tendency could increase in the future, as the industry has many concerns about the role of the public administration.

Therefore, first of all, and following the ACMA assessment framework (2011:13-15), we analyse in Table 2 whether "optimal conditions" or factors are present for co-regulating of the drone sector.

After this analysis, we can conclude that the majority of optimal factors are present, although some of them need to be enhanced. For example, Image 1 shows which risks were perceived by the industry in Spain in 2016, whereas two first risks were "a clear legal framework" and the "slowness of public administrations".

According to ACMA (2011) it is not necessary to cover all of them, but we suggest that if more co-regulation (not only for training) or self-regulation would like to be applied, more focus will be had on the regulatory scheme factors.

It is possible that these two concerns were the starting point to approve the Spanish Royal Decree 1036/2017 BOE, Government Official Bulletin, Royal Decree 1036, 29/12/2017), even before a new European regulation will come into force. This could be, at the moment, the latest national regulation for civil drones in Europe. At any rate, it does not separate the requirements into categories, but still distinguishes drones up to $25 \mathrm{~kg}$ from drones that are between 25 and $150 \mathrm{~kg}$.

This new regulation, however, gives the same authorisation for training to:

- Drone manufacturer or organisations authorised by a drone manufacturer.

- Licensed operator with own pilots.

- An authorised training organisation (ATO).

For being considered an ATO, article 5.h of the Royal Decree 2017 includes four categories: 
Table 2 ACMA assessment framework applied to the drone sector in Europe

\begin{tabular}{|c|c|c|c|}
\hline \multirow[t]{7}{*}{$\begin{array}{l}\text { Environmental } \\
\text { conditions }\end{array}$} & $\begin{array}{l}\text { Number of market } \\
\text { players and coverage of } \\
\text { the industry }\end{array}$ & $\begin{array}{l}\text { A small number of } \\
\text { players with wide } \\
\text { industry coverage will } \\
\text { facilitate effective } \\
\text { co-regulatory } \\
\text { arrangements }\end{array}$ & $\begin{array}{l}\text { The size of drone sector } \\
\text { is small compared to } \\
\text { others }\end{array}$ \\
\hline & $\begin{array}{l}\text { A competitive market } \\
\text { with few barriers to } \\
\text { entry }\end{array}$ & $\begin{array}{l}\text { Co-regulation is less } \\
\text { effective where there is } \\
\text { little competition or } \\
\text { where there is one large } \\
\text { player commanding sig- } \\
\text { nificant market power } \\
\text { that cannot be offset by } \\
\text { the rest of the industry }\end{array}$ & $\begin{array}{l}\text { The drone sector is } \\
\text { quite competitive and } \\
\text { many SMEs participate } \\
\text { in it. However, they } \\
\text { have to be aware of the } \\
\text { Chinese competition } \\
\text { (DJI as a big } \\
\text { competitor) }\end{array}$ \\
\hline & $\begin{array}{l}\text { Homogeneity of } \\
\text { products }\end{array}$ & $\begin{array}{l}\text { Co-regulation is less } \\
\text { effective where the } \\
\text { products in question are } \\
\text { varied and difficult to } \\
\text { compare, leading to } \\
\text { information asymmetry } \\
\text { and product confusion }\end{array}$ & $\begin{array}{l}\text { Products are very } \\
\text { homogenous, differ- } \\
\text { ences are based on the } \\
\text { sector they provide } \\
\text { their services }\end{array}$ \\
\hline & $\begin{array}{l}\text { Common industry } \\
\text { interest }\end{array}$ & $\begin{array}{l}\text { Existence of an industry } \\
\text { association that is either } \\
\text { representative of the } \\
\text { whole industry or gives } \\
\text { non-members incentives } \\
\text { to join }\end{array}$ & $\begin{array}{l}\text { The industry is grouped } \\
\text { into different national } \\
\text { and/or international } \\
\text { associations as well as } \\
\text { influenced by } \\
\text { specialised authorities }\end{array}$ \\
\hline & $\begin{array}{l}\text { Incentives for industry } \\
\text { to participate and } \\
\text { comply }\end{array}$ & $\begin{array}{l}\text { This can include a prod- } \\
\text { uct marketing value } \\
\text { proposition or customer } \\
\text { service advantage. Fur- } \\
\text { thermore, the threat of } \\
\text { government intervention } \\
\text { may provide a sufficient } \\
\text { incentive }\end{array}$ & $\begin{array}{l}\text { Training and mainte- } \\
\text { nance are great incen- } \\
\text { tives for the drone } \\
\text { manufacturers, which } \\
\text { are normally operators } \\
\text { as well. Moreover, } \\
\text { penalties can be applied } \\
\text { in case of } \\
\text { non-compliance }\end{array}$ \\
\hline & $\begin{array}{l}\text { The degree of consumer } \\
\text { detriment }\end{array}$ & $\begin{array}{l}\text { In cases of serious risk to } \\
\text { public health or safety, } \\
\text { direct regulation may be } \\
\text { more appropriate; how- } \\
\text { ever, intervention must } \\
\text { be proportionate to the } \\
\text { level of detriment }\end{array}$ & $\begin{array}{l}\text { Safety and security } \\
\text { concerns are present; } \\
\text { therefore, the participa- } \\
\text { tion of other stake- } \\
\text { holders is essential }\end{array}$ \\
\hline & $\begin{array}{l}\text { Whether it is a rapidly } \\
\text { changing environment }\end{array}$ & $\begin{array}{l}\text { Regulation that cannot } \\
\text { keep pace with develop- } \\
\text { ments will be ineffec- } \\
\text { tive, and may have } \\
\text { unintended and perverse } \\
\text { effects, become irrele- } \\
\text { vant and thus ignored by }\end{array}$ & $\begin{array}{l}\text { The drone sector is } \\
\text { developing very fast, its } \\
\text { environment changes } \\
\text { quickly }\end{array}$ \\
\hline
\end{tabular}


Table 2 (continued)

\begin{tabular}{|c|c|c|c|}
\hline & & $\begin{array}{l}\text { those intended to be } \\
\text { regulated, or become an } \\
\text { inappropriate mecha- } \\
\text { nism to address its orig- } \\
\text { inal purpose in a } \\
\text { changed environment }\end{array}$ & \\
\hline \multirow[t]{4}{*}{$\begin{array}{l}\text { Features of the } \\
\text { regulatory } \\
\text { scheme }\end{array}$} & $\begin{array}{l}\text { Whether the objectives } \\
\text { are clearly defined by } \\
\text { the government, legisla- } \\
\text { tion or the regulator }\end{array}$ & $\begin{array}{l}\text { It is optimal if policy- } \\
\text { makers and regulators } \\
\text { are clear on what objec- } \\
\text { tives, outcomes and } \\
\text { behavioural change they } \\
\text { are trying to effect } \\
\text { through co-regulatory } \\
\text { arrangements. A consis- } \\
\text { tent process for identi- } \\
\text { fying scope, } \\
\text { development, enforce- } \\
\text { ment and review is } \\
\text { required }\end{array}$ & $\begin{array}{l}\text { There are some differ- } \\
\text { ences among countries } \\
\text { that are also influenced } \\
\text { by the kind of "regula- } \\
\text { tory culture". Even if } \\
\text { the European Commis- } \\
\text { sion is putting big } \\
\text { efforts for a common } \\
\text { framework, the new } \\
\text { European regulation } \\
\text { has not been approved } \\
\text { yet }\end{array}$ \\
\hline & Role of the regulator & $\begin{array}{l}\text { Does the regulator pos- } \\
\text { sess the technical skills } \\
\text { to advise on industry } \\
\text { proposals? Does the } \\
\text { regulator have a clear } \\
\text { understanding of the } \\
\text { issues? Is data and } \\
\text { research available? }\end{array}$ & $\begin{array}{l}\text { In the drone sector, } \\
\text { EASA gives the main } \\
\text { guidelines and having a } \\
\text { specialised agency is a } \\
\text { must. This is the same } \\
\text { at the National level }\end{array}$ \\
\hline & $\begin{array}{l}\text { The existence and oper- } \\
\text { ation of transparency } \\
\text { and accountability } \\
\text { mechanisms }\end{array}$ & $\begin{array}{l}\text { The existence and oper- } \\
\text { ation of appropriate } \\
\text { sanctions to enforce } \\
\text { compliance and penalise } \\
\text { non-compliance are } \\
\text { important indicators of } \\
\text { effectiveness. Are } \\
\text { scheme members ade- } \\
\text { quately informed about } \\
\text { their obligations? }\end{array}$ & $\begin{array}{l}\text { EASA and the National } \\
\text { agencies give enough } \\
\text { information to the } \\
\text { industry, although it is } \\
\text { true that this depends } \\
\text { on the European } \\
\text { country }\end{array}$ \\
\hline & $\begin{array}{l}\text { Stakeholder participa- } \\
\text { tion in the development } \\
\text { of the scheme; in partic- } \\
\text { ular, consumer input } \\
\text { into the development of } \\
\text { co-regulatory } \\
\text { arrangements }\end{array}$ & $\begin{array}{l}\text { This could be direct } \\
\text { participation, such as } \\
\text { through consultation } \\
\text { processes. Or there } \\
\text { could be indirect repre- } \\
\text { sentation of stakeholder } \\
\text { interests, such as } \\
\text { through consumer or } \\
\text { audience research }\end{array}$ & $\begin{array}{l}\text { The European Com- } \\
\text { mission has undertaken } \\
\text { a general consultation } \\
\text { to all stakeholders in } \\
\text { order to develop the } \\
\text { new framework. Any- } \\
\text { way, more engagement } \\
\text { will be necessary at the } \\
\text { National level to apply } \\
\text { the arrangements }\end{array}$ \\
\hline
\end{tabular}


Table 2 (continued)

\begin{tabular}{|c|c|c|}
\hline $\begin{array}{l}\text { Whether the scheme is } \\
\text { promoted to consumers }\end{array}$ & $\begin{array}{l}\text { Scheme objectives } \\
\text { relating to consumer } \\
\text { protection are unlikely } \\
\text { to be met if consumers } \\
\text { and the community are } \\
\text { not made aware of its } \\
\text { operation and mecha- } \\
\text { nisms for redress }\end{array}$ & $\begin{array}{l}\text { It will be necessary to } \\
\text { give more information, } \\
\text { even if insurance is } \\
\text { compulsory in many } \\
\text { occasions }\end{array}$ \\
\hline
\end{tabular}

Source: own elaboration from ACMA (2011)

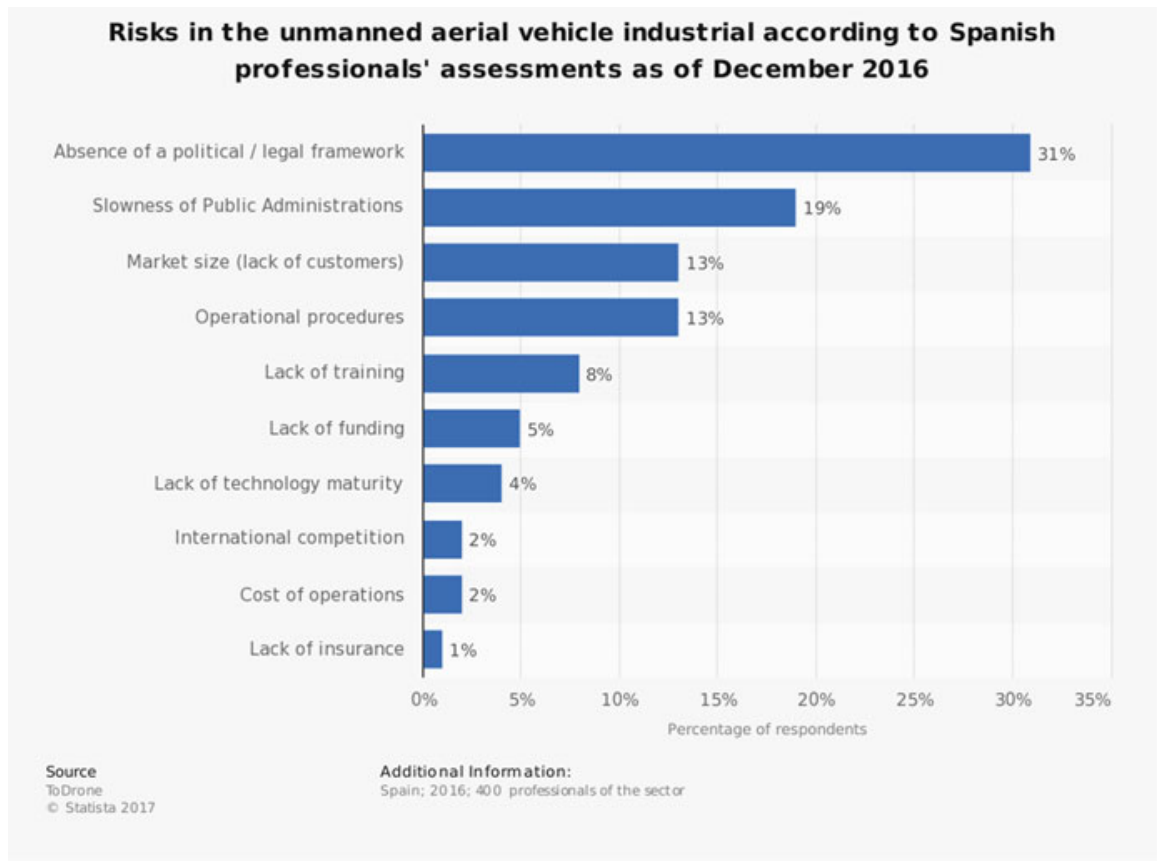

Image 1 Drone-related risks, according to industry in Spain (2016). Source: STATISTA (2017)

- School of ultralight vehicles.

- Non-engine flight school.

- Organisations with AESA qualification.

- Organisations that follow the Regulation (EU) n. 1178/2011 from the Commission, 3rd November 2011. That, at the same time, forward to the Regulation (EC) n. 216/2008. 
This latest Regulation (2008) specifies who can assess a civilian drone pilot: on the one hand, experienced operators and, on the other, ATOs. These ATOs must meet the following requirements:

- To have all the means necessary for the exercise of its functions and responsibilities associated with its activity. Among others, these means shall include: facilities, personnel, equipment, tools and material, documentation of tasks, responsibilities and procedures, access to relevant data and registration of data,

- Implement and maintain a safety-related management system and the level of training, and to propose the continuous improvement of this system, and

- If necessary, establish agreements with other relevant organisations to ensure continuous compliance with the above requirements.

After the training and its assessment of the pilot (as described by AESA), these organisations have to send to the Agency a dossier with all the required official documents. In this documentation, the drone type and model that the person is able to pilot should be specified. In Spain, AESA (2017b) publishes its list of ATOs in order to give publicity to the citizens and there we can check the models of drones that they have declared.

The pilot examination comprises three different parts: (a) theoretical knowledge, (b) practical training and (c) medical certificate (AESA 2017a).

Even if this certification is not necessary in all the cases, it could add value in cases of professional works. Moreover, licensed pilots contract insurance and this is another trust guarantee (article 26.c Royal Decree 2017). These licences are covered by many insurance companies, as we can compare in Image 2 .

In relation to these three parts for certificating the pilot requirements, Royal Decree 2017 has reduced some requirements in order to diminish regulation but increase co-regulation.

(a) Theoretical knowledge can be demonstrated in two ways (article 34 Royal Decree 2017):

- With a previous licence of any kind for piloting issued by AESA.

- In case of drones up to $25 \mathrm{~kg}$, with a Basic Training Course (for flights within the pilot's visual range) or with an Advanced Course (for flights beyond the pilot's visual range), developed by an ATO according to what is considered the minimum theoretical knowledge that an RPAS pilot should have.

Should an ATO wish to outsource the development of these courses to another organisation, it should include the specific RPAS programmes in its own, monitor and take responsibility for the content and include the trainers in its RPASspecific instructor cadre. They should also include in their own documentation specific to RPAS the units where the courses are given if they are not their own.

(b) Practical knowledge (article 36 Royal Decree 2017):

A flight book will be the proof that the pilot has enough training. At the end of a practical training course, a successful flight examination can lead to a certificate of 


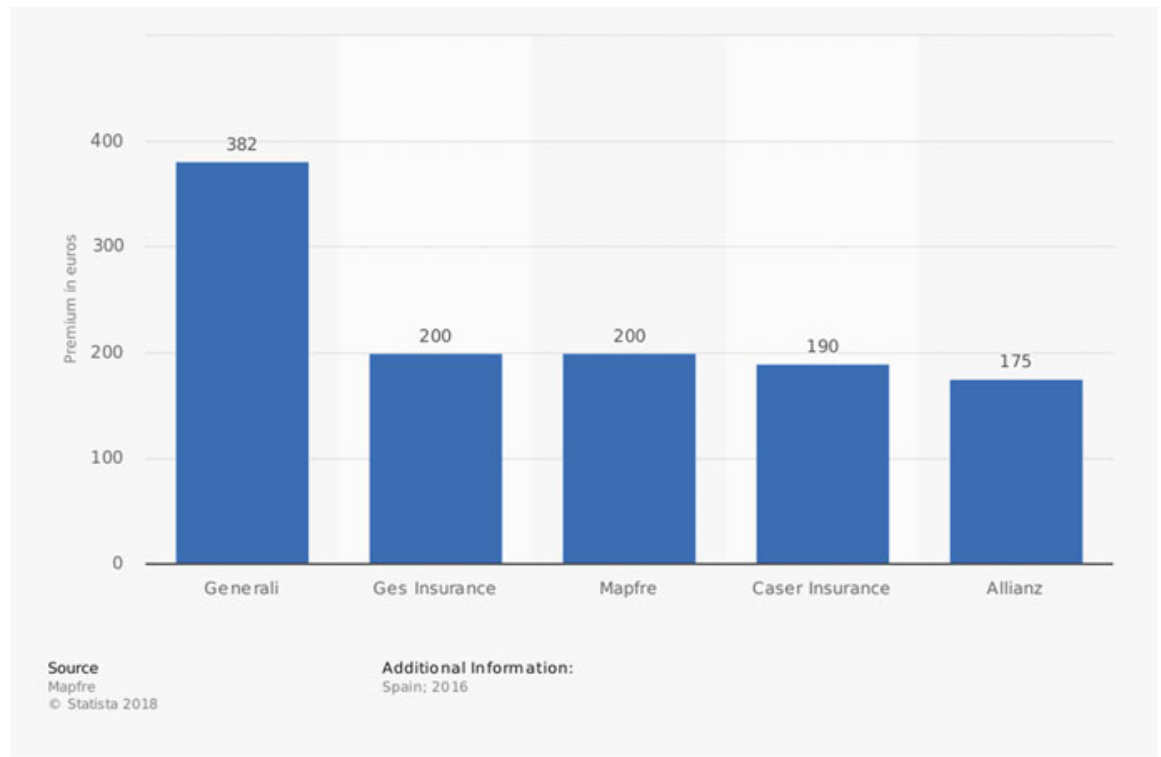

Image 2 Cost of civil liability insurance for drones (UAVs) of less than $25 \mathrm{Kg}$ in Spain in 2016, by Company (in euros). Source: STATISTA (2018)

satisfactory completion, specifying the type and model of aircraft for which the course has been taken. The certificate shall have a footnote indicating the name and position of the issuer. The operator may include in its responsible declaration or modification the aircraft type that can be operated.

This training can be covered by an ATO, an operator or a manufacturer. Pilots should take this flight book with them all the time to demonstrate that in the last 3 months they have performed at least three flights with a specific drone.

(c) Medical certificate (article 35 Royal Decree 2017):

Pilots operating aircraft up to $25 \mathrm{~kg}$ maximum take-off mass must hold at least one medical certificate laying down technical requirements and administrative procedures relating to civil aviation flight crew.

Pilots operating aircraft with a maximum take-off mass exceeding $25 \mathrm{~kg}$ must hold at least one Class 2 medical certificate, issued by an authorised aviation medical centre or an authorised aerial medical examiner.

Furthermore, in case a pilot would like to be enabled as an operator to give practical training to other pilots, two steps should be covered (AESA 2018a):

Step 1: Presentation of a previous communication to AESA.

Step 2: Carrying out the first flight as an operator to demonstrate that the intended operation(s) with the remote-controlled aircraft can be safely performed. 
They shall be conducted and documented in accordance with the AESA guidelines if required by the authority, but shall not be submitted to EASA.

The list of operators is also provided by AESA (2018b) and, at this moment, many of the 2810 operators are also manufacturers.

Other European countries use also co-regulation for training (De-Miguel-Molina and Carabal-Montagud 2018). For example, in the UK, the Civil Aviation Authority (CAA) gives this competence to the National Qualified Entities (NQEs) to conduct commercial operations with drones weighing $7 \mathrm{~kg}$ or less. In Belgium, the Direction Générale Transport Aérien (DGTA) gives this competence to some ATOs.

The case is different in Finland, where commercial pilots do not need to apply for any specific licence or certificate, but a report must be made online and manoeuvres documented in a flight book. According to the Finnish Transport Security Agency (TRAFI 2017), they only play an overseeing function, accepting operator notifications, giving permits, handling air space reservations, following occurrence reporting and taking actions on the basis of these information sources. This kind of "supervision" is more in line with the latest Spanish regulation, although some restrictions are still present.

At any rate, the new approach to regulate drones seems to reduce the requirements for training to operators and ATOs, and therefore the ATOs may not be necessary in the future if no licence or certification is compulsory and operator and pilot's responsibility is more focused on personal operation.

\section{Conclusions}

Even if different regulations, European or National, can distinguish different categories and requirements, we support the idea that operators should have the appropriate training to avoid any risk, even in the cases of small drones. Maybe if the industry is able to develop very precise drones, the pilots could be inexperienced people but, at this moment, we think that these cases should be reduced to indoor environments where the risks can be better assessed.

Although licences and certifications could be reduced in new regulations, a co-regulation where public agencies could give some kind of certificate will be an additional element to reinforce another kind of works where flight licences are not compulsory. Moreover, the necessity of a digital registration of some kind of drones, as proposed by the European Council (2018) or already present in some countries, such as Finland, could be reinforcement for the security of people in case of a drone failure.

The identification and registration of drones seems to be compulsory in the majority of countries, and linking each drone to its owner can help also to assign responsibilities for illegal activities.

As we have observed, by now in the European countries co-regulation is only centred on the operators and practical training. The participation of other stakeholders to ensure safety and security are not included. However, other agencies 
could be involved with the industry, for example, to ensure information security, product safety or data protection applying different best-practice standards.

In a sector where technology changes frequently, co-regulation will be necessary in order to update the current regulations to reflect the reality. For example, the Spanish regulation has again excluded transport activities even though their inclusion was expected (Sarrión Esteve and Benlloch Domènech 2017).

Moreover, from the side of regulation, the introduction of a compulsory, specific insurance could help. In the same line, citizens see drone regulations as analogous to car regulations, and therefore they should have "mandatory licensing, registration of devices, and mandatory third-party insurance" (Boucher 2016).

We analysed the latest national regulation of drones, the Spanish Royal Decree 2017, as a case study and a best practice to try to give a specific legal framework to the industry in order to avoid ambiguity. We have observed that the Spanish Agency, AESA, is constantly in touch with the industry and updates its information very frequently, which helps with better decision-taking.

\section{References}

ACMA (2011) Optimal conditions for effective self- and co-regulatory arrangements. Occasional paper. Australian Government. Available via ACMA. https://www.acma.gov.au/-/media/ mediacomms/Research-library-reports-old/Word-Document/Optimal-conditions-for-self--andco-regulation-Sep-2011-doc.doc?la=en. Accessed 13 Feb 2018

AESA (2017a) Drones, Spanish Agency of Aerial Security, Madrid. https://www.seguridadaerea. gob.es/lang_castellano/cias_empresas/trabajos/rpas/default.aspx. Accessed 7 Feb 2018

AESA (2017b) Authorised training organizations, Madrid. https://www.seguridadaerea.gob.es/ media/4357563/listado_atos_rpas.pdf. Accessed 7 Feb 2018

AESA (2018a) Steps to become and operator, Madrid. https://www.seguridadaerea.gob.es/media/ 4579489/procedimiento_habilitarse_operador_rpas.pdf. Accessed 12 Feb 2018

AESA (2018b) Register of responsible declaration of RPAs operators, Madrid. https://www. seguridadaerea.gob.es/media/4305572/listado_operadores.pdf. Accessed 7 Feb 2018

BOE (2017) Royal Decree 1036/2017, 15 December, of regulation of the use of civil drones. Spanish Ministry of Presidency and Regional Administrations, Madrid. https://www.boe.es/ boe/dias/2017/12/29/pdfs/BOE-A-2017-15721.pdf. Accessed 9 Feb 2018

Boucher P (2016) 'You wouldn't have your granny using them': drawing boundaries between acceptable and unacceptable applications of civil drones. Sci Eng Ethics 22:1391-1418

Catalá Pérez D (2017) La colaboración público-privada. In: De Miguel Molina M, Bañón Gomis AJ, Catalá Pérez D (eds) Management para las Administraciones públicas. Editorial Universitat Politècnica de València, Valencia, pp 131-158

Clarke R (2016) Appropriate regulatory responses to the drone epidemic. Comput Law Secur Rev 32(1):152-155

Clarke R, Bennett Moses L (2014) The regulation of civilian drones' impacts on public safety. Comput Law Secur Rev 30(3):263-285

Coglianese C, Mendelson E (2010) Meta-regulation and self-regulation. In: Baldwin R, Cave M, Lodge M (eds) The Oxford handbook of regulation. Oxford University Press, Oxford, pp $146-168$ 
Council of the European Union (2018) Proposal for a Regulation of the European Parliament and of the Council on common rules in the field of civil aviation and establishing a European Union Aviation Safety Agency, and repealing Regulation (EC) No 216/2008 of the European Parliament and of the Council. http://data.consilium.europa.eu/doc/document/ST-5218-2018-INIT/ en/pdf. Accessed 13 Feb 2018

De-Miguel-Molina M, Carabal-Montagud MA (2018) Legal and ethical recommendations. In: DeMiguel-Molina M, Santamarina-Campos V (eds) Ethics and civil drones. Proposals for the industry. Springer, Amsterdam, pp 77-86

De-Miguel-Molina M, Santamarina-Campos V (2018) Ethics and civil drones. Proposals for the industry. Springer, Amsterdam

Freeman PK, Freeland RS (2014) Politics and technology: U.S. polices restricting unmanned aerial systems in agriculture. Food Policy 49(1):302-311

Höffe O (2007) Ciudadano económico, ciudadano del Estado, ciudadano del mundo. Katz, Buenos Aires

Peters BG (2010) Meta-governance and public management. In: Osborne SP (ed) The new public governance? Routledge, London, pp 36-51

Sanderson P (2011) The citizen in regulation. A report for The Local Better Regulation Office. Technical report. University of Cambridge. Available via GOV.UK. https://www.gov.uk/gov ernment/uploads/system/uploads/attachment_data/file/262583/11-1473-citizen-in-regulation. pdf. Accessed 7 Feb 2018

Sarrión Esteve J, Benlloch Domènech C (2017) Rights and science in the drone era: actual challenges in the civil use of drone technology. Rights Sci:117-133

STATISTA (2017) Risks in the unmanned aerial vehicle industrial according to Spanish professionals' assessments as of December 2016. Statista-The Statistics Portal. Available via STATISTA. https:// www.statista.com/statistics/775963/drones-risks-from-the-industry-according-the-professionalsspanish-people/. Accessed 12 Feb 2018

STATISTA (2018) Cost of civil liability insurance for UAVs of less than $25 \mathrm{~kg}$ in Spain in 2016, by company (in euros). Statista-The Statistics Portal. Available via STATISTA. https://www. statista.com/statistics/773501/insurance-from-responsibility-civil-for-drones-cousin-by-insur ance-carrier-spain/. Accessed 12 Feb 2018

Stöcker C, Bennett R, Nex F et al (2017) Review of the current state of UAV regulations. Remote Sens 9(5):459-485

TRAFI (2017) Unmanned aviation. https://www.trafi.fi/en/aviation/unmanned_aviation/faq. Accessed 12 Feb 2018

Open Access This chapter is licensed under the terms of the Creative Commons Attribution 4.0 International License (http://creativecommons.org/licenses/by/4.0/), which permits use, sharing, adaptation, distribution and reproduction in any medium or format, as long as you give appropriate credit to the original author(s) and the source, provide a link to the Creative Commons license and indicate if changes were made.

The images or other third party material in this chapter are included in the chapter's Creative Commons license, unless indicated otherwise in a credit line to the material. If material is not included in the chapter's Creative Commons license and your intended use is not permitted by statutory regulation or exceeds the permitted use, you will need to obtain permission directly from the copyright holder.

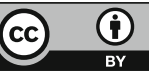

